\title{
Seminar on Nagssugtoqidian geology - an introduction
}

\author{
John A. Korstgård
}

The geological Survey of Greenland (GGU) was established in 1946 and its activities were initially concentrated on a hitherto relatively neglected part of Greenland - the Precambrian terrains of the central and southern west coast.

Field work started in 1946 with reconnaissance mapping of the country between latitudes $69^{\circ} \mathrm{N}$ and $63^{\circ} 45^{\prime} \mathrm{N}$ on the west coast of Greenland under the direction of A. Noe-Nygaard and $\mathrm{H}$. Ramberg. A reconnaissance map on a scale of 1:500 000 covering all areas accessible from the coast was published in 1961 (Noe-Nygaard \& Ramberg, 1961) with a brief description. Soon after the mapping started it became possible to divide the northern part of the Precambrian terrain into a southern, older fold belt and a northern, younger belt (the 'Nagssugtoqides') on the basis of the deformation and metamorphism of a pre-Nagssugtoqidian swarm of basic dykes - the Kangâmiut dykes. These early results were published in a now classic paper by Ramberg (1948).

Reconnaissance work in what was now called the Nagssugtoqidian mobile belt was resumed by GGU in 1965 (Escher, 1966), this time based on helicopter transport and now covering all ice-free parts. A new reconnaissance map, correcting and supplementing the 1961 map and covering the region Søndre Strømfjord - Nûgssuaq was published in 1971 (Geological map of Greenland, 1:500 000).

Concurrent with the new reconnaissance work by GGU a research project, the Agto 1 project, was conducted by E. Bondesen from Aarhus University. This project ran from 1966 to 1969 and involved detailing mapping, in co-operation with GGU, of a map sheet to be published on a scale of 1:100 000 (Bondesen, 1966). Mapping was resumed in 1975 and the Agto 2 project, under the direction of N. $\varnothing$. Olesen and K. Sørensen continued through 1978 when mapping was completed (Olesen $e t$ al., this volume).

The Liverpool Precambrian Boundary Programme, led by J. Watterson, had its origin in the GGU reconnaissance work for the 1971 Søndre Strømfjord - Nûgssuaq map sheet, and was concentrated in the Holsteinsborg-Itivdleq region. It had its first field season in 1972 and the results of the first two years of work are summarised by Watterson (1974).

Survey reconnaissance mapping of the Nagssugtoqidian terrains in South-East Greenland was started in 1967 (Bridgwater \& Gormsen, 1968) and is still going on (Bridgwater \& Myers, this volume).

Reconnaissance field work by GGU for the 1:500 000 map south of and joining the Søndre Strømfjord - Nûgssuaq sheet, which will cover the southern Nagssugtoqidian boundary in West Greenland, was completed in 1978 (Allaart \& Jensen, 1979).

By the end of the 1978 field season current Survey field work and field work related to the university projects on the west coast had been completed. It was therefore decided to organise a seminar so that results of field work and continuing laboratory work on the 
Nagssugtoqidian rocks could be discussed among the individuals involved in Nagssugtoqidian geology.

The seminar was organised by the Agto Group of the Department of Geology, Aarhus University and took place at the department's field station in Mønsted, 3-4 October 1978. 26 participants from U.S.A., Great Britain, the Universities of Copenhagen and Aarhus and the Geological Survey of Greenland attended the seminar. 24 talks were given and 15 of these are presented in this volume.

Two papers (Bridgwater \& Myers and Pedersen \& Bridgwater) deal exclusively with the Nagssugtoqidian in East Greenland. Six papers originate from the Liverpool Precambrian Boundary Programme (Talbot; Nash; Grocott; Korstgård; Nash; Davidson) and four papers stem from the Agto project (Olesen et al.; Hansen; Glassley \& Sørensen; Sørensen). Kalsbeek reviews recent isotopic age dating work done by GGU. Beckmann and Hickman have been involved in both the Liverpool as well as the Agto project and Beckmann also includes material from East Greenland.

Figure 1 shows the extent of the Nagssugtoqidian mobile belt in West Greenland. The map shows most of the major localities mentioned in the papers dealing with the west coast, and also shows those parts of the Nagssugtoqidian in West Greenland which the authors describe or from which material was collected.

The 15 papers in this volume represent reviews, research papers, and reports of ongoing work in the Nagssugtoqidian mobile belt in Greenland. They should be regarded as supplements to the article by Escher, Sørensen \& Zeck (1976) in the book Geology of Greenland published by GGU.

Looking back at Ramberg's 1948 paper it is a stricking tribute to his scientific perception that, notwithstanding the changes in interpretation inevitable in a rapidly developing subject, he was able so quickly to identify and focus attention on the critical features of this large and complicated area.

I would like to thank the Department of Geology, Aarhus University for providing financial support and the Geological Survey of Greenland for its willingness to publish papers presented at the seminar. A special thanks must go to the editor of GGU, W. Stuart Watt, for the support and interest he has shown in producing this volume.

\section{References}

Allaart, J. H. \& Jensen, S. B. 1979: Completion of 1:500 000 reconnaissance mapping in the Precambrian of the Evighedsfjord - Søndre Strømfjord - Itivdleq region, southern West Greenland. Rapp. Grønlands geol. Unders. 95, 72-76.

Bondesen, E. 1966: Research on the high-metamorphic complexes of the Agto area. Rapp. Grønlands geol. Unders. 11, 20-23.

Bridgwater, D. \& Gormsen, K. 1968: Precambrian rocks of the Angmagssalik area, East Greenland. Rapp. Gronlands geol. Unders. 15, 61-71.

Bridgwater, D. \& Myers, J. S. 1979: Outline of the Nagssugtoqidian mobile belt of East Greenland. Rapp. Gronlands geol. Unders. 89 (this volume).

Escher, A. 1966: New geological recannaissance mapping in the area between Nordre Strømfjord and Ikertoq fjord. Rapp. Grønlands geol. Unders. 11, 24-25.

Escher, A., Sørensen, K. \& Zeck, H. P. 1976: Nagssugtoqidian mobile belt in West Greenland. In Escher, A. \& Watt, W. S. (edit.) Geology of Greenland, 77-95. Copenhagen: Geol. Surv. Greenland. 
Noe-Nygaard, A. \& Ramberg, H. 1961: Geological reconnaissance map of the country between latitudes $69^{\circ} \mathrm{N}$ and $63^{\circ} 45^{\prime} \mathrm{N}$, West Greenland. Meddr Grønland 123 (5), 9 pp.

Olesen, N. Ø., Korstgård, J. A. \& Sørensen, K. 1979: A summary of lithology and structure within the Agto map sheet (67 V.1 Nord), Nagssugtoqidian mobile belt, West Greenland. Rapp. Grønlands geol. Unders. 89 (this volume).

Ramberg, H. 1948: On the petrogenesis of the gneiss complexes between Sukkertoppen and Christianshaab, West Greenland. Meddr dansk geol. Foren. 11, 312-327.

Watterson, J. 1974: Investigations on the Nagssugtoqidian boundary in the Holsteinsborg district, central West Greenland. Rapp. Grønlands geol. Unders. 65, 33-37.

Geologisk Institut,

Aarhus Universitet,

DK-8000 Árhus C,

Denmark. 